Original Research

\title{
Polycyclic Aromatic Hydrocarbons in Different Layers of Soil and Groundwater - Evaluation of Levels of Pollution and Sources of Contamination
}

\author{
Predrag Ilić1*, Dragana Nešković Markić², Ljiljana Stojanović Bjelić², \\ Zia Ur Rahman Farooqi ${ }^{3}$ \\ ${ }^{1}$ PSRI Institute for Protection and Ecology of the Republic of Srpska, Vidovdanska 43, Banja Luka, \\ Republic of Srpska, Bosnia and Herzegovina \\ ${ }^{2}$ Pan-European University “Apeiron”, Pere Krece 13, Banja Luka, Republic of Srpska, Bosnia and Hercegovina \\ ${ }^{3}$ Institute of Soil and Environmental Sciences, University of Agriculture, Faisalabad-38040, Pakistan
}

Received: 27 March 2020

Accepted: 20 July 2020

\begin{abstract}
This study examined the concentrations of 16 polycyclic aromatic hydrocarbons (PAHs) in soil and groundwater at a former cellulose factory in the city of Banja Luka, Republic of Srpska, Bosnia and Herzegovina. The objective of the study was to determine the concentrations of 16 PAHs in soil and groundwater at the site. The research area consisted of four representative locations in the industrial complex where the soil was sampled at depths of $0.3,1,2,3$, and $4 \mathrm{~m}$ and groundwater was sampled at $3.10,2.50$ and $3 \mathrm{~m}$ for two samples. In addition to the $16 \mathrm{PAHs}$, soil organic matter content and $\mathrm{pH}$ were also measured. The sum of the 16 PAHs ( $\Sigma 16 \mathrm{PAHs}$ ) in soil ranged from 0.99 to $2.24,0.34$ to $0.46,0.24$ to $0.32,0.13$ to 0.27 and 0.13 to $0.47 \mathrm{mg} / \mathrm{kg}$ for the $0.3,1,2,3$, and $4 \mathrm{~m}$ depths, respectively. Mean values were $1.70,0.40,0.28,0.20$ and $0.26 \mathrm{mg} / \mathrm{kg}$, respectively. The $\Sigma 16 \mathrm{PAHs}$ in groundwater ranged from 0.23 to $4.50 \mathrm{mg} / \mathrm{m}^{3}$, with a mean value of $1.42 \mathrm{mg} / \mathrm{m}^{3}$. The concentrations of all 16 PAHs in the soil decreased with depth and there was no significant correlation between the concentrations of PAHs in the soil and groundwater. The concentrations of PAHs in the soil surface $(0.3 \mathrm{~m})$ and groundwater indicate that this industrial site is heavily contaminated and might need remedial action. Factor analysis indicates three sources of contamination, i.e. principal component (PC) PC1 (pyrogenic), PC2 (petrogenic) and PC3 (biomass), with $52.39 \%, 26.14 \%$ and $8.46 \%$ of the total variance, respectively. The results of this study reflect the effects of coal combustion (pyrogenic origin), petrogenic and biomass origin and may provide basic data for the remediation of PAHs in the location.
\end{abstract}

Keywords: soil, groundwaters, polycyclic aromatic hydrocarbons (PAHs), industrial complex, source of contamination

*e-mail: predrag.ilic@institutzei.net 


\section{Introduction}

Polycyclic aromatic hydrocarbons (PAHs) are a large group of organic compounds containing two or more benzene rings in their structure. Polycyclic aromatic hydrocarbons (PAHs) result from anthropogenic activities, i.e. industrial emissions, incomplete combustion of petroleum, coal and other fossil fuels and other industrial and domestic activities [1-6]. Natural sources of PAHs are volcanoes, bacterial and algal synthesis, forest fires, petroleum seeps, erosion of sedimentary rocks containing petroleum hydrocarbons and decomposition of vegetative litterfall [7]. These compounds are widely present in the air, water, aquatic system, soils and sediments [8]. Although there are more than 100 different types of PAHs, [9] most analyses and data reports typically focus on 14 and 20 individual PAHs on average. PAHs can be divided into two categories: low molecular weight compounds are 2and 3- rings (molecular weight $<200 \mathrm{~g} / \mathrm{mol}$ ) and high molecular weight compounds are 4-, 5-, 6-ring PAHs (molecular weight $>200 \mathrm{~g} / \mathrm{mol}$ ). Pure PAHs are usually colored, crystalline solids at ambient temperature [10], and they have high melting and boiling points, low vapor pressure and very low aqueous solubility. These compounds are very soluble in organic solvents and are lipophilic [11-12].

There is a large number of studies of PAHs in soils of different countries, namely Germany [13], France [14], Austria [15], China [16], USA [17], South Africa [18], Antarctic [19]. In their study, Brindha \& Elango [20] have identified the presence of PAHs in groundwater in Chennai, Tamil Nandu, India. Li et al. [21] have researched the behavior of PAHs in surface and groundwater of the Yellow River, China, while Sun et al. [22] study focused on vertical migration of PAHs from surface soils to groundwater.

Systematic studies on PAHs contamination in surface soil in Bosnia and Herzegovina have been rare, and the research of PAHs at different soil depths was never conducted. Still, some analyses of PAHs in soil, air and sediment were carried out. One such analysis was of playground soil in the city of Sarajevo [23]. An investigation of POPs and PAHs in ambient air in the Central and Eastern Europe was also conducted in Bosnia and Herzegovina [24], as well as analyses of POPs and PAHs in sediments of the Neretva River [25]. A study of air PAHs in urban and rural areas was done in the City of Banja Luka in 2008 [26, 27]. The results of this study show that the value of PAHs in the urban area was much higher than in the rural area.

The most important and valuable aspect of this study is that soil samples have been taken from different layers, up to $4 \mathrm{~m}$ in depth, while in other studies, the greatest sampling depths were up to $20 \mathrm{~cm} \mathrm{[28],} 40 \mathrm{~cm}$ [6], $50 \mathrm{~cm} \mathrm{[3]} \mathrm{and} 100 \mathrm{~cm} \mathrm{[22].}$

This study examined the concentrations of 16 PAHs in soil and groundwater in an industrial complex (locality Incel) (former Cellulose Factory) in the city of Banja Luka, Republic of Srpska, Bosnia and Herzegovina. The main objective of the paper is to determine the concentration levels, evaluate contamination of soil and groundwater in locations with high pollution in the city of Banja Luka and to assess the probable sources of PAHs contamination in soil and groundwater in locations.

\section{Material and Methods}

\section{Location Sampling}

The subject of the research in the study was to measure the PAHs concentration in the soil and groundwater in the industrial complex in Banja Luka. Banja Luka is the second largest city in the Republic of Srpska, Bosnia and Herzegovina, with a population of 185,000 . The city is situated in a basin $164 \mathrm{~m}$ above sea level. The average annual temperature reaches $10.7^{\circ} \mathrm{C}$. The lowest temperatures range between $-5.6^{\circ} \mathrm{C}$ and $-27^{\circ} \mathrm{C}$ and the highest between $31.4^{\circ} \mathrm{C}$ and $41.4^{\circ} \mathrm{C}$.

The former industrial complex originally manufactured cellulose, viscose and paper products. Established in 1954, it was a major industrial conglomerate during the Socialist Era, employing up to 6,500 workers. Following a period of decline in the 1980s and the War in Bosnia and Herzegovina in 1990s, the factory building was destroyed, and the manufacturing itself was subsequently split into several smaller enterprises. This industrial complex is situated $3 \mathrm{~km}$ from the city centre. Incel factory was heavily damaged which resulted in the emission of various toxic substances into the neighboring environment. Location is categorized as a hotspot (waste from cellulose and viscose factory) [29, 30]. This location was selected for research due to earlier studies that discovered high contamination with heavy metals $(\mathrm{Cd}, \mathrm{Pb}, \mathrm{Ni}, \mathrm{Cu}$, and $\mathrm{Hg}$ ) and organic pollutants (Polychlorinated Biphenyls (PCB) and Total Petroleum Hydrocarbons (TPH)) [29] and PAH [30]. Soil and groundwater analyses were carried out at multiple spots and wells (piezometers) dug out and specially installed for this, as well as the future groundwater research (S1, S2, S3, and S4) (Fig. 1).

\section{Analysis}

A total of 16 soil and 4 groundwater samples were collected from four locations in the industrial complex, from different layers of soil (at a depth of $30 \mathrm{~cm}$, $100 \mathrm{~cm}, 200 \mathrm{~cm}, 300 \mathrm{~cm}$, and $400 \mathrm{~cm}$ ) and groundwater was sampled at 3.10, 2.50 and $3 \mathrm{~m}$ for two samples from saturated zone. The depth of the wells is $3 \mathrm{~m}$ in one location and $4 \mathrm{~m}$ in three locations.

Soil and groundwater samples were collected during August 2019. Chemical analyses were conducted for 16 types of PAHs by using Gas chromatography. The detector used for PAH analysis is a mass detector coupled 


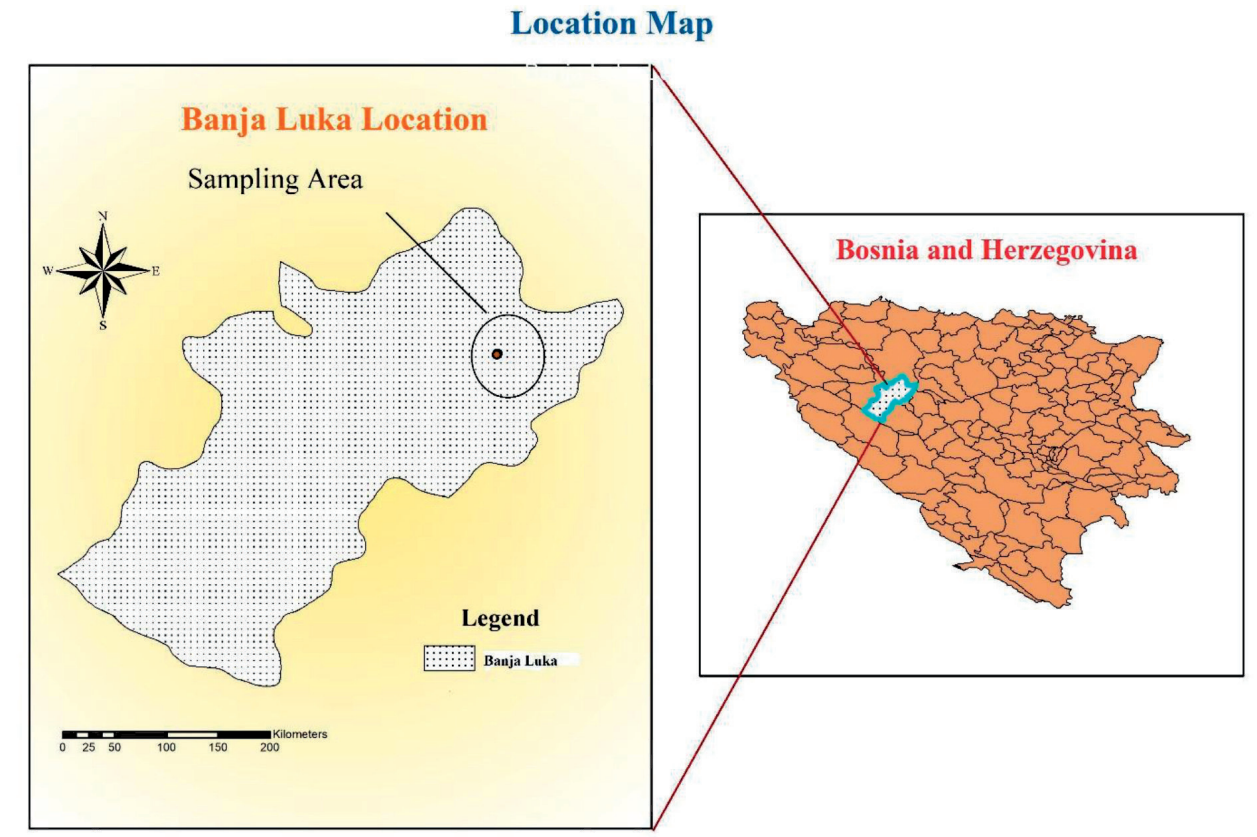

Fig. 1. Location of sampling.

to a gas chromatograph (GC-MS). The physical analyses conducted in the soil were: acidity $(\mathrm{pH})$ measured in deionized water, and organic matter (humus) content applying Tyurin's method [31]. Components of PAHs that were analysed were: low molecular weight PAHs (LMWPAHs) with 2 and 3 aromatic rings such as naphthalene (Nap, 2-ring), acenaphthylene (Acy, 3-ring), acenaphthene (Ace, 3-ring), fluorine (Flo, 3-ring), phenanthrene (Phe, 3-ring) and anthracene (Ant, 3-ring) and high molecular weight PAHs (HMWPAHs) with 4-6 aromatic rings such as fluoranthene (Fluo, 4-ring) pyrene (Pyr, 4-ring) benzo[a]anthracene (BaA, 4-ring), chrysene (Chr, 4-ring), benzo[b]fluoranthene (BbF, 5-ring), benzo[k]fluoranthene (BkF, 5-ring), benzo[a]pyrene (BaP, 5-ring), indeno[1,2,3-cd]pyrene (IcdP, 6-ring), dibenzo[a,h]anthracene (DahA, 5-ring) and benzo[g,h,i]perylene (BghiP, 6-ring). The process of extraction and obtained PAHs concentrations were further processed based on the principles described in standard methods with disintegration techniques and analysed in accordance with national legislation $[32,33]$ and accredited standard method EPA 8270D/3550C:2007 for soil and EPA 8270D/EPA 3510 for water [34]. Accredited quantification limit for $\mathrm{PAH}$ in soil is $0,02 \mathrm{mg} / \mathrm{kg}$ and for water $0,03 \mathrm{ug} / \mathrm{l}$.

\section{Statistical Analysis}

Descriptive statistical operations like mean, median (med), minimum (min), maximum ( $\max$ ), and Skewness test were applied for the analysis of the measured data. Pearson's correlation with significance level of $p$-value: $\mathrm{p}<0.05, \mathrm{p}<0.01$, and $\mathrm{p}<0.001$ was used. Excel 2016 and JASP v0.8.5.1 software tools were used for statistical data processing.

\section{Results and Discussion}

\section{Basic Characteristics of PAHs Concentrations in Soils and Groundwater}

Table 1 shows the descriptive statistics of the 16 priority PAHs compounds in contaminated soils (at a depth of up to $30 \mathrm{~cm}$ (surface layer), $100 \mathrm{~cm}, 200 \mathrm{~cm}$, $300 \mathrm{~cm}$, and $400 \mathrm{~cm}$ ) and groundwater environmental samples in four locations of the examined area. In this research, the $\sum 16 \mathrm{PAHs}$ in the soil (at a depth of up to $30 \mathrm{~cm}, 100 \mathrm{~cm}, 200 \mathrm{~cm}, 300 \mathrm{~cm}, 400 \mathrm{~cm}$ ) ranged from 0.99 to $2.24 \mathrm{mg} / \mathrm{kg}$, from 0.34 to 0.46 , from 0.24 to 0.32 , from 0.13 to 0.27 and from 0.13 to 0.47 , with mean values of $1.70 \mathrm{mg} / \mathrm{kg}, 0.40 \mathrm{mg} / \mathrm{kg}, 0.28 \mathrm{mg} / \mathrm{kg}$, $0.20 \mathrm{mg} / \mathrm{kg}$ and $0.26 \mathrm{mg} / \mathrm{kg}$, respectively. The $\sum 16$ PAHs in groundwater ranged from 0.23 to $4.50 \mathrm{mg} / \mathrm{m}^{3}$, with a mean value of $1.42 \mathrm{mg} / \mathrm{m}^{3}$. According to the national standards [32], the concentrations of $\sum 16 \mathrm{PAHs}$ found in this study are higher in one location and lower in other locations than the permissible value of $2 \mathrm{mg} / \mathrm{kg}$ in agricultural soils. The soil is heavily contaminated (heavily polluted) according to permissible limits of $1 \mathrm{mg} / \mathrm{kg}$ [35] in a surface layer of soil $(0-30 \mathrm{~cm})$ and contamination in soils was 1-2.24 times higher than limits.

The $\sum 16 \mathrm{PAHs}$ in groundwater ranged from 0.23 to $4.50 \mathrm{mg} / \mathrm{m}^{3}$, with a mean value of $1.41 \mathrm{mg} / \mathrm{m}^{3}$. The measured value indicates that groundwater is highly polluted and classified in the fifth class of water quality, and those are heavily polluted waters that can be used for almost no purpose [33]. Among the $\sum 16 \mathrm{PAHs}$, the three most abundant were Phe $\left(0.87 \mathrm{mg} / \mathrm{m}^{3}\right)$, Nap $\left(0.64 \mathrm{mg} / \mathrm{m}^{3}\right)$ and $\mathrm{BaA}\left(0.62 \mathrm{mg} / \mathrm{m}^{3}\right)$.

The $\sum 16$ PAHs are the highest in the surface layer of 


\begin{tabular}{|c|c|c|c|c|c|c|c|c|c|c|c|c|c|c|c|c|c|c|}
\hline \multirow{3}{*}{ 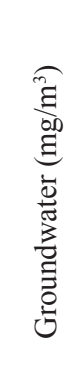 } & $\mid \begin{array}{c}0 \\
\infty \\
\tilde{E} \\
\simeq\end{array}$ & 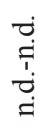 & $\begin{array}{l}\dot{I} \\
\dot{T} \\
\dot{d} \\
\dot{d}\end{array}$ & \begin{tabular}{|l}
$\dot{d}$ \\
$\dot{T}$ \\
$\dot{T}$ \\
$\dot{J}$ \\
\end{tabular} & 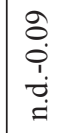 & 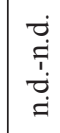 & 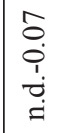 & 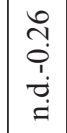 & $\begin{array}{l}\hat{n} \\
0 \\
i \\
\dot{0} \\
\ddot{n}\end{array}$ & \begin{tabular}{|l} 
\\
0 \\
0 \\
$\vdots$ \\
0 \\
0 \\
0
\end{tabular} & $\begin{array}{l}0 \\
0 \\
0 \\
0 \\
1 \\
\dot{1} \\
\dot{u}\end{array}$ & $\begin{array}{l}0 \\
0 \\
0 \\
0 \\
0 \\
0 \\
0\end{array}$ & 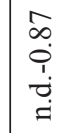 & 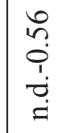 & $\begin{array}{l}\tilde{J} \\
0 \\
0 \\
\tilde{d} \\
0 \\
0\end{array}$ & 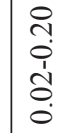 & 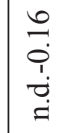 & 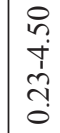 \\
\hline & $\sum_{\Sigma}^{\Xi}$ & ' & ' & ' & $\stackrel{8}{\circ}$ & ' & $\stackrel{8}{\circ}$ & $\stackrel{0}{\circ}$ & $\stackrel{\overbrace{}}{\circ}$ & $\stackrel{\simeq}{0}$ & $\stackrel{\circ}{\circ}$ & ᄋ̣̊. & $\stackrel{0}{0}$ & $\stackrel{1}{0}$ & $\stackrel{0}{\circ}$ & $\stackrel{\leftrightarrow}{\circ}$ & $\stackrel{\circ}{\circ}$ & : \\
\hline & $\sum_{\Sigma}^{\mathbb{E}}$ & 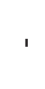 & ' & ' & O̊. & ' & $\underset{ْ}{\stackrel{O}{0}}$ & $\begin{array}{l}\hat{0} \\
\dot{0}\end{array}$ & $\stackrel{n}{0}$ & $\stackrel{-}{0}$ & $\stackrel{m}{0}$ & $\stackrel{7}{0}$ & $\stackrel{\overbrace{}}{0}$ & $\begin{array}{l}0 \\
0 \\
0\end{array}$ & $\stackrel{9}{0}$ & o. & 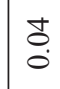 & $\stackrel{\text { I }}{\mathrm{-}}$ \\
\hline
\end{tabular}

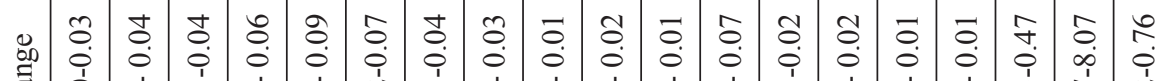

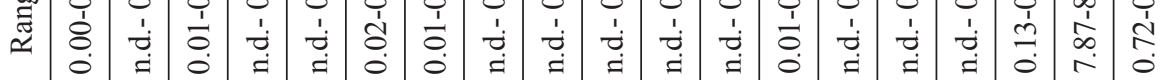
घี

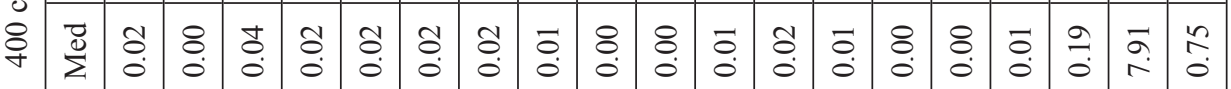

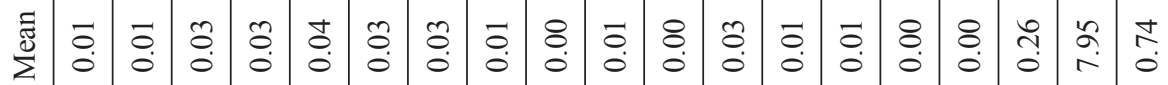

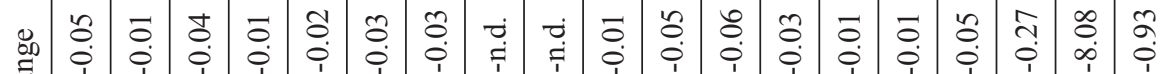

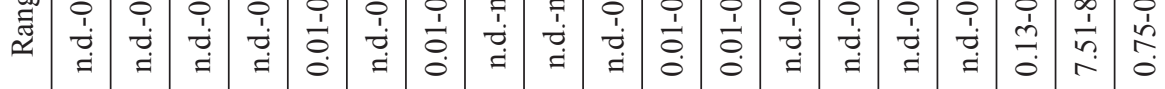

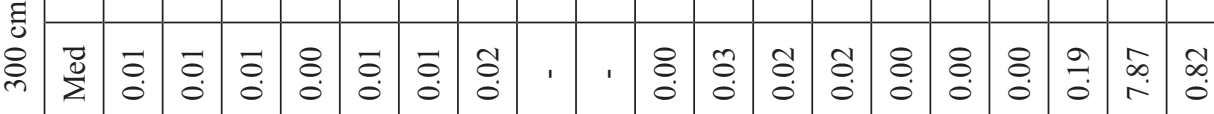

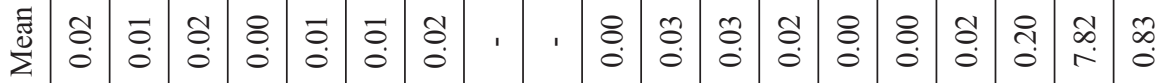
क्रि

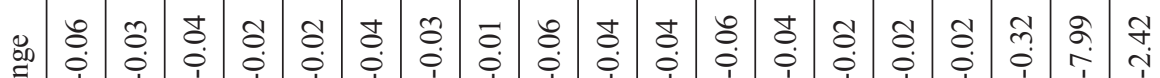

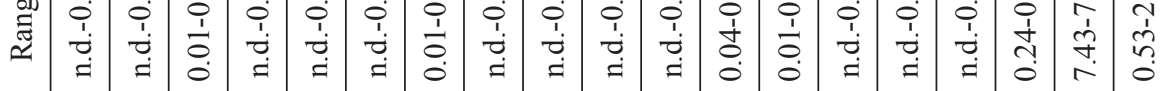
氙

. is

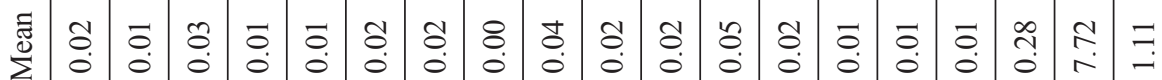
它

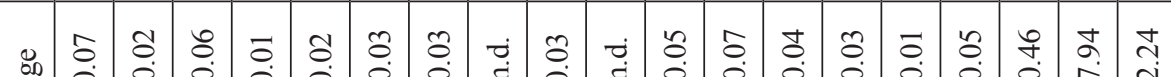
ีㅡㅁ

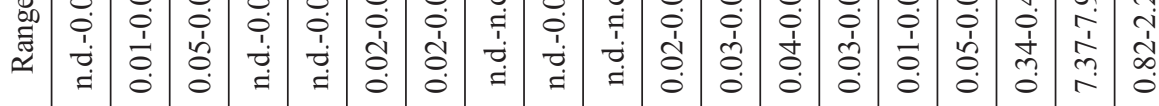

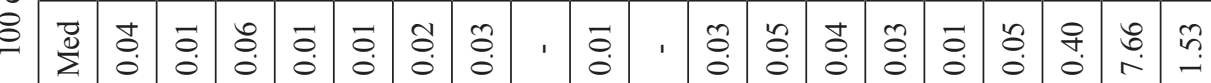
䔍

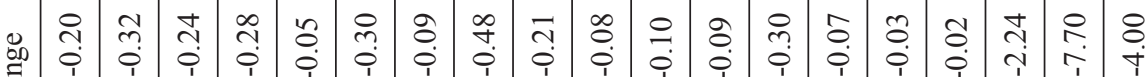

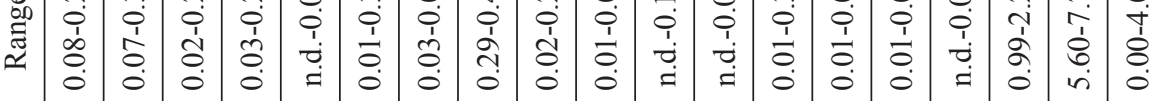
हี

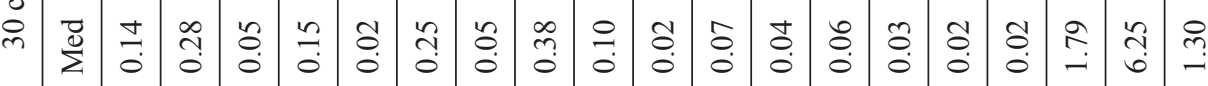

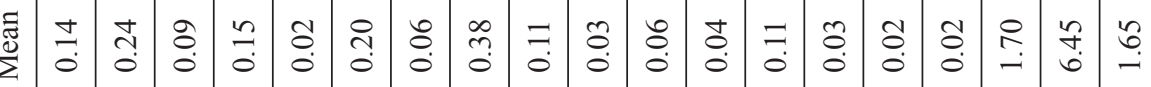
党 פั:

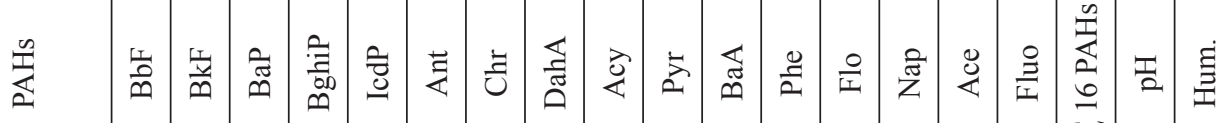




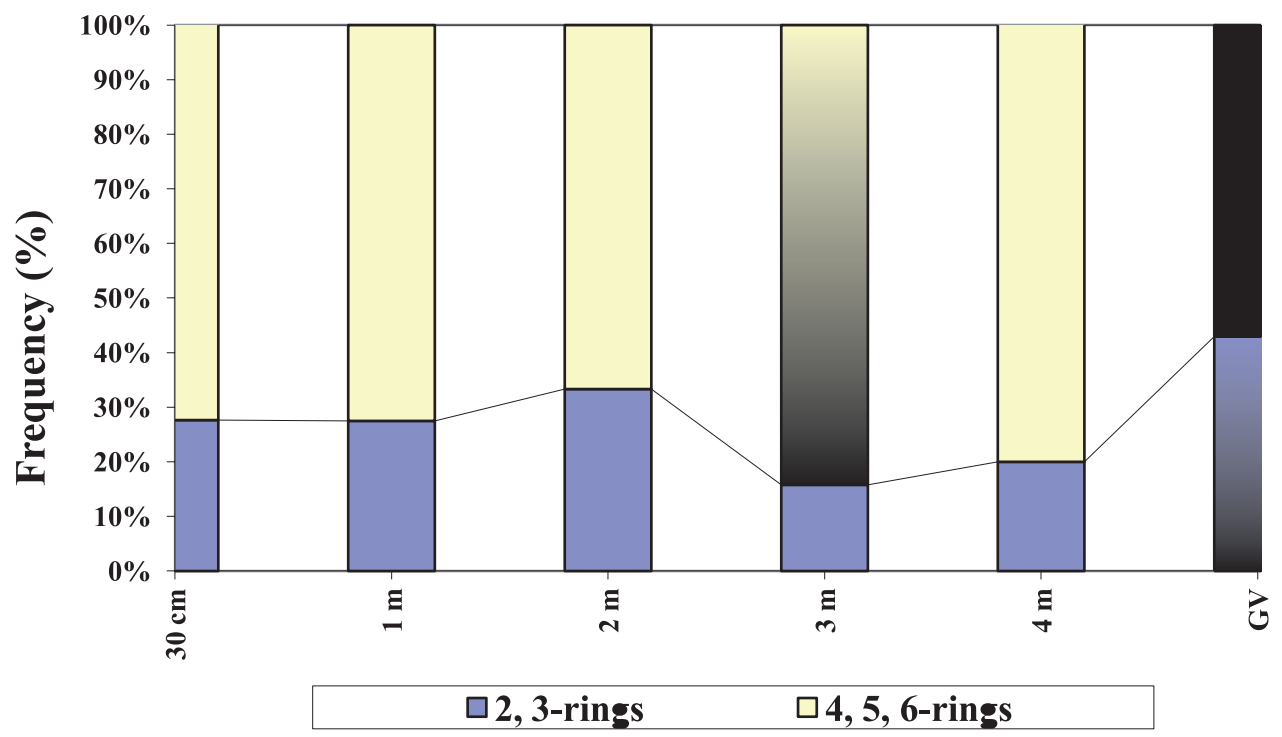

Fig. 2. Frequency of PAHs per ring in soil and groundwater for low and high molecular PAHs.

soil, and with increasing the depth it decreases. Similar results were also observed in Shenyang City in China, where the PAH concentrations decreased with the depth of the soil [36]. Jiao et al. [37] came up with a similar result of decreasing concentration of $\sum 16 \mathrm{PAHs}$ by increasing the depth in the study (Shanxi, China) and explained that PAHs come from pyrolysis inputs due to industrial emissions formed and released during industrial activities and also shows the migrate trend of PAHs in the vertical section of the soils [37]. Comparing the concentrations of $\sum \mathrm{PAHs}$ in soils in the Loess Plateau, China, similar values were obtained in the surface layer of soil [3], in an urban location in China [6], 6 times higher than values in the Hunpu region, a wastewater-irrigated area, Shenyang City, China [36]. Values of PAHs in these locations are higher than values along the Govan to Clydebank corridor, the area with a history of heavy industry (concentrations range from $86.9-653 \mathrm{mg} / \mathrm{kg}$ ) [38], similar as in examined locality. Values are 10 times lower than values in Glasgow soils and 2 times higher than values in Ljubljana and Torino soils [4].

The distribution of the 2 and 3-ring (low molecular) and 4, 5, 6-ring (high molecular) PAHs are shown in Fig. 2. The PAHs frequency in surface soils $(0-30 \mathrm{~cm})$ was detected as 2 and 3-rings (28\%) and 4, 5 and 6-ring (72\%). High percentages of high molecular PAHs (4, 5, 6-rings) are found at all depths in the soil, and in lesser quantities in the water. The percentage representation of low molecular PAHs (2, 3, 4-rings) was highest in groundwater.

\section{Correlation Analysis of PAHs and Soil Properties}

Tables 2 and 3 present the correlation analysis (Pearson correlation test). Table 2 shows correlations between the determined PAHs values in the surface layer of soil in each location and PAHs values per different soil layers and groundwater. Table 3 displays the correlation analysis for PAHs components $(p<0.05$, $\mathrm{p}<0.00) \quad(\mathrm{p}-$ Pearson's rank correlation). Bolded numbers indicate a statistically significant correlation $(\mathrm{r}>0.5)$.

Table 2. Correlation per layers of soil and groundwater.

\begin{tabular}{|c|c|c|}
\hline & \multicolumn{2}{|c|}{ Pearson's correlation } \\
\hline & $\mathrm{r}$ & $\mathrm{p}$ \\
\hline S1 Surface layer - S1 $100 \mathrm{~cm}$ & $0.977 * * *$ & $<.001$ \\
\hline S1 Surface layer - S1 $200 \mathrm{~cm}$ & $0.922 * * *$ & $<.001$ \\
\hline S1 Surface layer - S1 $300 \mathrm{~cm}$ & $0.931 * * *$ & $<.001$ \\
\hline S1 Surface layer - S1 $400 \mathrm{~cm}$ & $0.921 * * *$ & $<.001$ \\
\hline S1 Surface layer - S1 Groundwater & 0.143 & 0.598 \\
\hline S2 Surface layer - S2 $100 \mathrm{~cm}$ & $0.991 * * *$ & $<.001$ \\
\hline S2 Surface layer - S2 $200 \mathrm{~cm}$ & $0.995 * * *$ & $<.001$ \\
\hline S2 Surface layer - S2 $300 \mathrm{~cm}$ & $0.993 * * *$ & $<.001$ \\
\hline S2 Surface layer - S2 Groundwater & $0.619 *$ & 0.011 \\
\hline S3 Surface layer - S3 $200 \mathrm{~cm}$ & $0.949 * * *$ & $<.001$ \\
\hline S3 Surface layer - S3 $300 \mathrm{~cm}$ & $0.992 * * *$ & $<.001$ \\
\hline S3 Surface layer - S3 $400 \mathrm{~cm}$ & $0.993 * * *$ & $<.001$ \\
\hline S3 Surface layer - S3 Groundwater & -0.061 & 0.824 \\
\hline S4 Surface layer - S4 $200 \mathrm{~cm}$ & $0.966 * * *$ & $<.001$ \\
\hline S4 Surface layer - S4 $400 \mathrm{~cm}$ & $0.965 * * *$ & $<.001$ \\
\hline S4 Surface layer - S4 Groundwater & -0.329 & 0.214 \\
\hline
\end{tabular}

$* \mathrm{p}<0.05, * * * \mathrm{p}<0.001$. 
Table 3. Correlation per PAHs components of soil and groundwater.

\begin{tabular}{|c|c|c|c|c|c|c|c|c|}
\hline \multicolumn{9}{|c|}{ Pearson's correlation test ( $\mathrm{r}$ and $\mathrm{p}$ values) } \\
\hline Nap-Acy & $0.679 * * *$ & $<.001$ & Ace-DahA & -0.145 & 0.543 & Fluo-BaP & $0.862 * * *$ & $<.001$ \\
\hline Nap-Ace & $0.726^{* * *}$ & $<.001$ & Ace-BghiP & 0.005 & 0.982 & Fluo-IcdP & $0.919 * * *$ & $<.001$ \\
\hline Nap-Flo & $0.761 * * *$ & $<.001$ & Flo-Phe & $0.490^{*}$ & 0.028 & Fluo-DahA & $0.900 * * *$ & $<.001$ \\
\hline Nap-Phe & 0.249 & 0.290 & Flo-Ant & $0.775 * * *$ & $<.001$ & Fluo-BghiP & $0.852 * * *$ & $<.001$ \\
\hline Nap-Ant & $0.696^{* * *}$ & $<.001$ & Flo-Fluo & 0.414 & 0.070 & Pyr-BaA & 0.133 & 0.575 \\
\hline Nap-Fluo & 0.155 & 0.514 & Flo-Pyr & $0.453^{*}$ & 0.045 & Pyr-Chr & -0.011 & 0.964 \\
\hline Nap-Pyr & $0.556^{*}$ & 0.011 & Flo-BaA & 0.431 & 0.058 & Pyr-BbF & 0.017 & 0.943 \\
\hline Nap-BaA & 0.120 & 0.613 & Flo-Chr & 0.270 & 0.249 & Pyr-BkF & -0.080 & 0.738 \\
\hline Nap-Chr & -0.068 & 0.775 & Flo-BbF & 0.297 & 0.203 & Pyr-BaP & 0.205 & 0.386 \\
\hline Nap-BbF & -0.036 & 0.882 & Flo-BkF & 0.142 & 0.551 & Pyr-IcdP & 0.017 & 0.944 \\
\hline Nap-BkF & -0.161 & 0.498 & Flo-BaP & $0.476^{*}$ & 0.034 & Pyr-DahA & 0.047 & 0.845 \\
\hline Nap-BaP & 0.103 & 0.664 & Flo-IcdP & 0.222 & 0.347 & Pyr-BghiP & -0.081 & 0.735 \\
\hline Nap-IcdP & -0.111 & 0.641 & Flo-DahA & 0.198 & 0.402 & $\mathrm{BaA}-\mathrm{Chr}$ & $0.841 * * *$ & $<.001$ \\
\hline Nap-DahA & -0.112 & 0.639 & Flo-BghiP & 0.203 & 0.390 & $\mathrm{BaA}-\mathrm{BbF}$ & $0.851 * * *$ & $<.001$ \\
\hline Nap-BghiP & -0.030 & 0.901 & Phe-Ant & 0.380 & 0.098 & $\mathrm{BaA}-\mathrm{BkF}$ & $0.810^{* * *}$ & $<.001$ \\
\hline Acy-Ace & 0.171 & 0.470 & Phe-Fluo & 0.012 & 0.959 & $\mathrm{BaA}-\mathrm{BaP}$ & $0.780 * * *$ & $<.001$ \\
\hline Acy-Flo & 0.411 & 0.071 & Phe-Pyr & 0.059 & 0.804 & BaA-IcdP & $0.835^{* * *}$ & $<.001$ \\
\hline Acy-Phe & 0.140 & 0.557 & Phe-BaA & -0.098 & 0.680 & BaA-DahA & $0.873 * * *$ & $<.001$ \\
\hline Acy-Ant & $0.649 * *$ & 0.002 & Phe-Chr & -0.090 & 0.706 & BaA-BghiP & $0.698 * * *$ & $<.001$ \\
\hline Acy-Fluo & 0.086 & 0.719 & Phe-BbF & -0.105 & 0.659 & $\mathrm{Chr}-\mathrm{BbF}$ & $0.984 * * *$ & $<.001$ \\
\hline Acy-Pyr & $0.699^{* * *}$ & $<.001$ & Phe-BkF & -0.178 & 0.454 & Chr-BkF & $0.978 * * *$ & $<.001$ \\
\hline Acy-BaA & 0.036 & 0.879 & Phe-BaP & 0.007 & 0.976 & Chr-BaP & $0.930 * * *$ & $<.001$ \\
\hline Acy-Chr & -0.047 & 0.843 & Phe-IcdP & -0.156 & 0.511 & Chr-IcdP & $0.983 * * *$ & $<.001$ \\
\hline Acy-BbF & -0.045 & 0.851 & Phe-DahA & -0.198 & 0.403 & Chr-DahA & $0.962 * * *$ & $<.001$ \\
\hline Acy-BkF & -0.097 & 0.683 & Phe-BghiP & -0.108 & 0.650 & Chr-BghiP & $0.858 * * *$ & $<.001$ \\
\hline Acy-BaP & 0.116 & 0.625 & Ant-Fluo & 0.254 & 0.280 & $\mathrm{BbF}-\mathrm{BkF}$ & $0.975 * * *$ & $<.001$ \\
\hline Acy-IcdP & -0.098 & 0.680 & Ant-Pyr & $0.613 * *$ & 0.004 & $\mathrm{BbF}-\mathrm{BaP}$ & $0.931 * * *$ & $<.001$ \\
\hline Acy-DahA & -0.056 & 0.815 & Ant-BaA & 0.345 & 0.137 & BbF-IcdP & $0.986 * * *$ & $<.001$ \\
\hline Acy-BghiP & -0.098 & 0.681 & Ant-Chr & 0.135 & 0.569 & BbF-DahA & $0.968 * * *$ & $<.001$ \\
\hline Ace-Flo & $0.765^{* * *}$ & $<.001$ & Ant-BbF & 0.175 & 0.461 & BbF-BghiP & $0.909 * * *$ & $<.001$ \\
\hline Ace-Phe & 0.401 & 0.079 & Ant-BkF & 0.078 & 0.744 & $\mathrm{BkF}-\mathrm{BaP}$ & $0.874 * * *$ & $<.001$ \\
\hline Ace-Ant & $0.532 *$ & 0.016 & Ant-BaP & 0.327 & 0.159 & BkF-IcdP & $0.974 * * *$ & $<.001$ \\
\hline Ace-Fluo & 0.149 & 0.531 & Ant-IcdP & 0.079 & 0.740 & BkF-DahA & $0.955^{* * *}$ & $<.001$ \\
\hline Ace-Pyr & 0.227 & 0.337 & Ant-DahA & 0.105 & 0.659 & BkF-BghiP & $0.879 * * *$ & $<.001$ \\
\hline Ace-BaA & 0.144 & 0.545 & Ant-BghiP & 0.115 & 0.629 & BaP-IcdP & $0.917 * * *$ & $<.001$ \\
\hline Ace-Chr & -0.100 & 0.675 & Fluo-Pyr & 0.039 & 0.871 & BaP-DahA & $0.897 * * *$ & $<.001$ \\
\hline Ace-BbF & -0.047 & 0.844 & Fluo-BaA & $0.857 * * *$ & $<.001$ & BaP-BghiP & $0.817 * * *$ & $<.001$ \\
\hline Ace-BkF & -0.164 & 0.490 & Fluo-Chr & $0.935^{* * *}$ & $<.001$ & IcdP-DahA & $0.982 * * *$ & $<.001$ \\
\hline Ace-BaP & 0.012 & 0.960 & Fluo-BbF & $0.941 * * *$ & $<.001$ & IcdP-BghiP & $0.884 * * *$ & $<.001$ \\
\hline Ace-IcdP & -0.109 & 0.646 & Fluo-BkF & $0.919 * * *$ & $<.001$ & DahA-BghiP & $0.865 * * *$ & $<.001$ \\
\hline
\end{tabular}

$* \mathrm{p}<0.05, * * \mathrm{p}<0.01, * * * \mathrm{p}<0.001$. 
The results of the correlation analysis between the PAHs values of surface soil in each location and PAHs values in soil layers and groundwater are considered to have a strong positive statistically significant correlation $(r>0.5)$. Correlation with PAHs values in groundwater is weak, which confirms that the site soil is not the only cause of groundwater pollution. An additional source of pollution may arise from other polluted sites, which have reached the site via groundwater flow.

Correlations of Nap with Acy, Ace, Flo, Ant, and Pyr; Acy with Ant and Pyr; Ace with Flo and Ant; Flo with Ant; Ant with Pyr; Fluo with $\mathrm{BaA}, \mathrm{Chr}, \mathrm{BbF}$ and BkF; Fluo with BaP, IcdP, DahA and BghiP; BaA with Chr, BbF, BkF, BaP, IcdP, DahA and BghiP; Chr with $\mathrm{BbF}, \mathrm{BkF}, \mathrm{BaP}$, IcdP, DahA and BghiP; BbF with BkF, $\mathrm{BaP}$, IcdP, DahA and BghiP; BkF with BaP, IcdP, DahA and BghiP, BaP with IcdP, DahA and BghiP; IcdP with DahA and BghiP; DahA with BghiP are strong positive correlations. These results suggest that these pollutant pairs might have similar sources or result from similar factors.

In location je type of soil is clay. $\mathrm{pH}$ values in $\mathrm{H}_{2} \mathrm{O}$ are from 7.37 to 8.07 in samples. Organic matter (\%) are from 0.53 to 2.42 . Due to their hydrophobicity and nonpolarity, PAHs merge with soil organic matter (SOM) or humus colloids in soil [38]. SOM plays the role of PAHs carrier for downward migration and protects PAHs from the degradation. Fine particle clays have a larger specific surface area or have more adsorption sites, showing a higher sorption capacity of PAH compared to fine or coarse sand [22].

SOM has a high sorption capacity, limiting PAHs to the upper part of the soil profile thereby reducing the concentration of PAHs with the depth. Organic matter is of great importance for the sorption of hydrophobic organic compounds (among other things PAHs). Its content is higher than $8 \%$ while the combined effect of organic matter and clay mineral is manifested at its content below $6 \%$ [39].

The physical and chemical composition of the soil is responsible for retaining PAHs in soil. The quantities of organic $\mathrm{C}$ and hydrophobicity of organic matter in soil are estimated as the most important parameter for PAH retention in the environment [40, 41].

A correlation analysis between $216 \mathrm{PAHs}$, humus (organic matter) and $\mathrm{pH}$ in soil was conducted in the present study. A statistically moderate negative correlation was found between $\sum 16 \mathrm{PAHs}$ and $\mathrm{pH}$. The value of $r$ is -0.655 ( $p$-value is $<0.01$ ). The significant correlation between $\sum 16 \mathrm{PAHs}$ and humus has not been determined in the study. There is probably a lasting input of fresh PAHs (from the biomass heating plant in close proximity as well as the traffic) which confirms the correlation. Nam et al. [42] obtained similar results.

\author{
Factor, Principal Components \\ and Cluster Analysis
}

Factor and principal components analysis (FA and PCA) are multivariate statistical methods to identify the main factors that determine the variability of environmental quality [43].

The relationship between the components of PAHs levels in soils and groundwater with anthropogenic activities was examined, using FA. FA was employed to determine the effective variable factors (compounds). The varimax rotation was used for component loading for PAHs components in soil and groundwater (Table 4). The aim of FA was to create a fewer number of factors by combining two or more variables. The primary output for a PCA shows the correlation between each variable of a principal component and the variable factors (PC1, PC2, and PPC3), i.e. elements in soil samples are affected by two major components. Three principal components (PC) have eigenvalues higher than 1 (PC1, PC2, and PC3).

The RC1 factor included $\mathrm{BaA}, \mathrm{BaP}, \mathrm{BbF}, \mathrm{BghiP}$, BkF, Chr, DahA, Fluo and IcdP was identified according to their coefficients in the component matrix. The $\mathrm{PCl}$ factor is in relation to coal combustion, i.e. burning and vehicular emissions and was indicative of the pyrogenic origin, especially Fla, Pyr, BaA, BbF, $\mathrm{BkF}, \mathrm{BaP}, \mathrm{BghiP}$, and IcdP [44]. According to Liu et al. [45], all components were strong positively loaded if values were $>0.75$, and moderately loaded if values were in the range from 0.75-0.5 (Table 4). Harrison et al. [46] reported that compounds Fluo, $\mathrm{BaA}$, and $\mathrm{Chr}$ were typical markers for coal combustion. The $\mathrm{PC} 1$ factor explained $52.39 \%$ of the total variance. Davis et al. [47] also reported that BghiP and IcdP sources were from the vehicular exhaust. According to Iwegbue et al. [48] $\mathrm{Chr}, \mathrm{BkF}$ and DahA are indicators of diesel emissions and BghiP and IcdP originate through combustion of heavy oil.

The PC2 factor that includes Acy, Ant, Nap and Pyr was identified as well, and it explains $26.14 \%$ of the total variance. This factor is of petrogenic origin. Acy component was strong positively loaded $(>0.75)$ [45] (Table 1). Furthermore, Davis et al. [47] pointed out that Acy is the main product of a petroleum source. Ant and Pyr were also strong positively loaded, if the value were $>0.70$ [49]. Nap acts as a marker for petroleum source [50] as well as for mineral oils [44]. The petrogenic source is probably directly contaminated by illegal waste disposal and petroleum leaks in location and characterized by the predominance of 2- or 3-ring PAHs.

The PC3 factor includes components that were strong positively loaded Ace, Flo $(>0.75)$ and Phe $(>0.70)$ $[45,49]$. Ant and Nap were moderately loaded, as their values ranged from $0.75-0.5$. This factor contains 3 - and 4-ring PAH compounds of biomass origin and explains $8.46 \%$ of the total variance. Loadings of Phe and Ant were higher and represent low-temperature processes 
Table 4. Component loading for PAHs components in soil and groundwater, according to factor analysis.

\begin{tabular}{|c|c|c|c|c|}
\hline & PC 1 & PC 2 & PC 3 & Uniqueness \\
\hline Ace & . & . & 0.874 & 0.197 \\
\hline Acy & . & 0.906 & . & 0.171 \\
\hline Ant & . & 0.702 & 0.531 & 0.195 \\
\hline $\mathrm{BaA}$ & 0.875 & . & . & 0.198 \\
\hline $\mathrm{BaP}$ & 0.930 & . & . & 0.094 \\
\hline $\mathrm{BbF}$ & 0.996 & . & . & 0.009 \\
\hline BghiP & 0.904 & . & . & 0.175 \\
\hline $\mathrm{BkF}$ & 0.977 & . & . & 0.027 \\
\hline Chr & 0.987 & . & . & 0.024 \\
\hline DahA & 0.979 & . & . & 0.025 \\
\hline Flo & . & . & 0.796 & 0.072 \\
\hline Fluo & 0.948 & . & . & 0.067 \\
\hline IcdP & 0.989 & . & . & 0.014 \\
\hline Nap & . & 0.690 & 0.587 & 0.178 \\
\hline Phe & . & . & 0.741 & 0.436 \\
\hline Pyr & . & 0.895 & . & 0.198 \\
\hline Eigenvalue & 8.38 & 4.18 & 1.35 & \\
\hline Variance (\%) & 52.39 & 26.14 & 8.46 & \\
\hline $\begin{array}{l}\text { Total variance } \\
\text { (Cum \%) }\end{array}$ & 52.39 & 78.53 & 86.99 & \\
\hline
\end{tabular}

of wood/biomass combustion, i.e. the incomplete combustion of wood/biomass [47]. Zeng et al. [6] explained that the Flo compounds were characteristic of coal combustion. The probable cause is a wood-burning plant nearby.
Three components accounted for $86.99 \%$ of the total variance, highlighting the major trends of the soil ecosystem. The source analysis of soil PAHs demonstrated that the main causes of PAHs are coal combustion (pyrogenic) (PC1 factor), petroleum sources (petrogenic) (PC2 factor) and biomass combustion (PC3 factor).

PCA provides information on the most significant parameters [51]. Fig. 3a) shows which PCA is done to combine measured variables in three components, $\mathrm{PC1}$, PC2, and PC3. The direction of the arrows shows that variables, i.e. PAHs components (Ace, Acy, Ant, BaA, BaP, BbF, BghiP, BkF, Chr, DahA, Flo, Fluo, IcdP Nap, Phe, and Pyr) contribute to the three variable factors. The weights to emphasize are $\mathrm{BaA}, \mathrm{BaP}, \mathrm{BbF}$, BghiP, BkF, Chr, DahA, Fluo and IcdP (for PC1), Acy, Nap and Pyr (for PC2) and Phe, Flo, and Ace (for PC3) variables that stand out more than others.

Fig. 3b) shows PCA scree plot (varimax rotation) with eigenvalues higher than one, as a criterion for evaluating the components required to explain the origin of variance in the data. Three factors explained $86.99 \%$ of the data in total variance.

Hierarchical cluster analysis (CA), an analytical technique for multivariate data analysis [21] was applied to the data, and the Paired group (UPGMA) method distance was chosen for calculation (Fig. 4). CA was performed to check the results of the PC analysis and provided details of similarities between groups of parameters [52].

The results of the CA yield a slightly similar result like PCA. From the results, three main groups can be identified. Acy and Pyr (Group 1) and Phe, Chr, IcdP, DahA, BghiP, Fluo, BbF and BkF (Group 2) and Ant, Nap, Ace, BaA, Flo and BaP (Group 3), indicating that the pollutants in the similar group might have similar sources (Fig. 4), which was also confirmed by PCA. a)

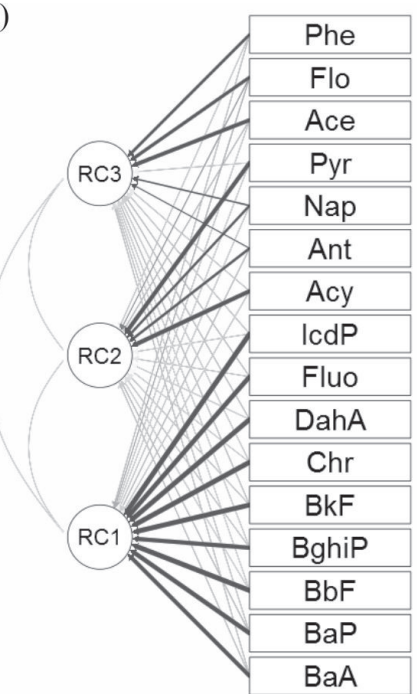

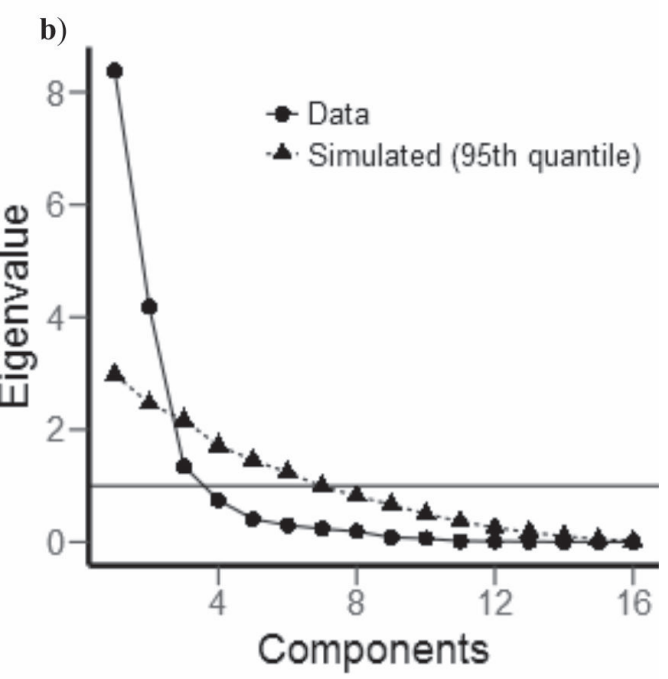

Fig. 3. a) Path diagram; b) Scree plot. 


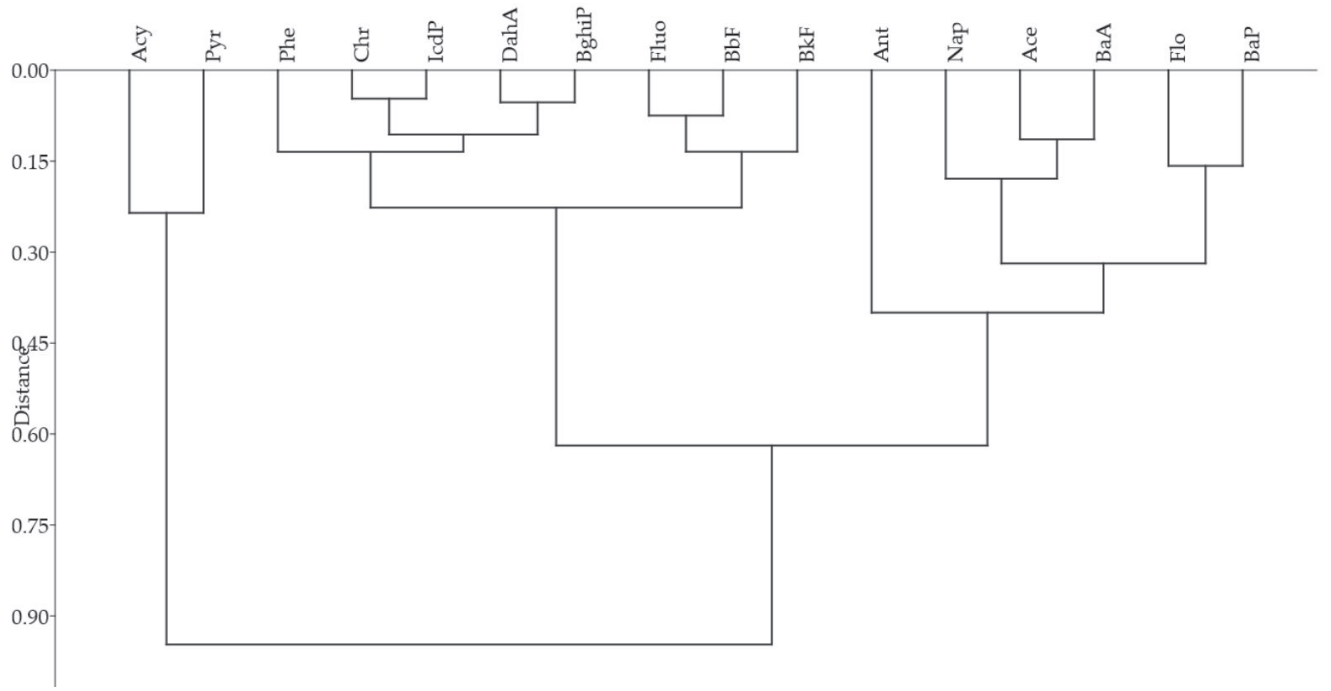

Fig. 4. Path hierarchical clustering analysis per PAHs components.

\section{Conclusions}

This research found that the $\sum 16 \mathrm{PAHs}$ in the soil (at a depth of up to $30 \mathrm{~cm}, 100 \mathrm{~cm}, 200 \mathrm{~cm}, 300 \mathrm{~cm}$ and $400 \mathrm{~cm}$ ) ranged from 0.99 to $2.24 \mathrm{mg} / \mathrm{kg}$, from 0.34 to 0.46 , from 0.24 to 0.32 , from 0.13 to 0.27 and from 0.13 to 0.47 , with mean values of $1.70 \mathrm{mg} / \mathrm{kg}, 0.40 \mathrm{mg} / \mathrm{kg}$, $0.28 \mathrm{mg} / \mathrm{kg}, 0.20 \mathrm{mg} / \mathrm{kg}$ and $0.26 \mathrm{mg} / \mathrm{kg}$, respectively. The $\Sigma 16 \mathrm{PAHs}$ in groundwater ranged from 0.23 to $4.50 \mathrm{mg} / \mathrm{m}^{3}$, with a mean value of $1.42 \mathrm{mg} / \mathrm{m}^{3}$. According to the national standards, the concentrations of $\sum 16$ PAHs found in this study are higher in one location and lower in other locations than the permissible value of $2 \mathrm{mg} / \mathrm{kg}$ in agricultural soils. Soil and groundwater are heavily contaminated (heavily polluted) in the surface layer of soil $(0-30 \mathrm{~cm})$. The study indicated that PAHs concentration in the industrial complex and in different layers of soil and groundwater were high. The significantly higher values of $\sum 16 \mathrm{PAHs}$ in the surface soil layer compared to other soil layers indicate that there is a fresh intake of PAHs at the site, with preexisting historical pollution. The measured value also indicates that groundwater is highly polluted and that groundwater is classified in the fifth class of water quality, and those are heavily polluted waters that can be used for almost no purpose. The flow of groundwater has a significant influence in PAH concentrations since a significantly higher concentration of PAHs is observed in groundwater compared to the soil at research sites. The $\sum 16 \mathrm{PAHs}$ is the highest in surface layer of soil, and with increasing the depth it decreases.

Maximum $\sum 16$ PAHs values were observed at 0-30 $\mathrm{cm}$ and PAH concentrations decreased with depth in the different soil layers, and PAHs were dominantly accumulated in the surface soil layer.

The relationship between the components of PAHs levels in soils and groundwater and anthropogenic activities was examined, using factor analysis (FA). Three components accounted for $86.99 \%$ of the total variance. The source analysis of soil PAHs demonstrated that the main causes of PAHs are coal combustion (pyrogenic) ( $\mathrm{PCl}$ factor included $\mathrm{BaA}$, $\mathrm{BaP}, \mathrm{BbF}, \mathrm{BghiP}, \mathrm{BkF}, \mathrm{Chr}$, DahA, Fluo, and IcdP), petroleum sources (petrogenic) (PC2 factor included Acy, Ant, Nap and Pyr) and biomass combustion (PC3 factor included Ace, Flo, and Phe). The results of the hierarchical cluster analysis (CA) yield a slightly similar result like principal components analysis. From the results, three main groups can be identified. Acy and Pyr (Group 1) and Phe, Chr, IcdP, DahA, BghiP, Fluo, $\mathrm{BbF}$, and BkF (Group 2) and Ant, Nap, Ace, BaA, Flo, and $\mathrm{BaP}$ (Group 3).

\section{Acknowledgements}

The present study was conducted using equipment from the PSRI Institute for Protection and Ecology of the Republic of Srpska, Banja Luka. This research was done in the frame of project "Environmental assessment correlated with the environmental risks in the urban area", granted by the Ministry for Scientific and Technological Development, Higher Education and Information Society of Republic of Srpska (19/6020/961-96/18).

\section{Conflict of Interest}

The authors declare no conflict of interest.

\section{References}

1. GUO J., CHAI C., GE W., ZENG L., WU J., XIANG D., ZHANG X. Accumulation and Health Risk Assessment of PAHs in Radish. Pol. J. Environ. Stud. 27 (6), 2529, 2018. 
2. DING Y., HUANG H., ZHANG Y., ZHENG H., ZENG F., CHEN W., QU C., LI X., QI S. Polycyclic aromatic hydrocarbons in agricultural soils from Northwest Fujian, Southeast China: Spatial distribution, source apportionment, and toxicity evaluation. Journal of Geochemical Exploration. 195, 121, 2018.

3. WANG D., MA J., LI H., ZHANG X. Concentration and potential ecological risk of PAHs in different layers of soil in the petroleum-contaminated areas of the Loess Plateau, China. Int. J. Environ. Res. Public Health. 15 (8), 1785, 2018,

4. ALSBOU E., ZAITOUN M.A., ALASOUFI A.M., AL SHRA'AH A. Concentration and Source Assessment of Polycyclic Aromatic Hydrocarbons in the Street Soil of Ma'an City, Jordan. Archives of environmental contamination and toxicology. 77 (4), 619, 2019.

5. THIOMBANE M., ALBANESE S., DI BONITO M., LIMA A., ZUZOLO D., ROLANDI R., QI S., DE VIVO B. Source patterns and contamination level of polycyclic aromatic hydrocarbons (PAHs) in urban and rural areas of Southern Italian soils. Environmental geochemistry and health. 41 (2), 507, 2019.

6. ZENG S., MA J., REN Y., LIU G.J., ZHANG Q., CHEN F. Assessing the Spatial Distribution of Soil PAHs and their Relationship with Anthropogenic Activities at a National Scale. Int. J. Environ. Res. Public Health. 16 (24), 4928, 2019.

7. ABDEL-SHAFY H.I., MANSOUR M.S.M. A review on polycyclic aromatic hydrocarbons: source, environmental impact, effect on human health and remediation. Egypt J Petroleum. 25 (1), 107, 2016.

8. NADAL M., SCHUHMACHER M., DOMINGO J.L. Levels of PAHs in soil and vegetation samples from Tarragona County, Spain. Environ. Pollut. 132 (1), 1, 2004.

9. LAMICHHANE S., KRISHNA K.B., SARUKKALIGE R. Polycyclic aromatic hydrocarbons (PAHs) removal by sorption: a review. Chemosphere. 148, 336, 2016.

10. KIM K.H., JAHAN S.A., KABIR E., BROWN R.J. A review of airborne polycyclic aromatic hydrocarbons (PAHs) and their human health effects. Environ. Int. 60, 71, 2013.

11. HUSSAIN K., HOQUE R.R., BALACHANDRAN S., MEDHI S., IDRIS M.G., RAHMAN M., HUSSAIN F.L. Monitoring and risk analysis of PAHs in the environment. In: Handbook of Environmental Materials Management, Hussain, C., Eds.; Publisher: Springer, Cham, 1, 2018.

12. SKUPINSKA K., MISIEWICZ I., KASPRZYCKAGUTTMAN T. Polycyclic aromatic hydrocarbons: physicochemical properties, environmental appearance and impact on living organisms. Acta Pol. Pharm. 61 (3), 233, 2004.

13. AICHNER B., BUSSIAN B.M., LEHNIK-HABRINK P., HEIN S. Regionalized concentrations and fingerprints of polycyclic aromatic hydrocarbons (PAHs) in German forest soils. Environ. Pollut. 203, 31, 2015.

14. MOTELAY-MASSEI A., OLLIVON D., GARBAN B., TEIL M.J., BLANCHARD M., CHEVREUIL M. Distribution and spatial trends of PAHs and PCBs in soils in the Seine River basin, France. Chemosphere. 55 (4), 555, 2004.

15. WEISS P., RISS A., GSCHMEIDLER E., SCHENTZ $\mathrm{H}$. Investigation of heavy metal, $\mathrm{PAH}, \mathrm{PCB}$ patterns and $\mathrm{PCDD} / \mathrm{F}$ profiles of soil samples from an industrialized urban area (Linz, Upper Austria) with multivariate statistical methods. Chemosphere. 29 (9-11), 2223, 1994.
16. ZUO Q., DUAN Y.H., YANG Y., WANG X.J., TAO S. Source apportionment of polycyclic aromatic hydrocarbons in surface soil in Tianjin, China. Environ. Pollut. 147 (2), 303, 2007.

17. MIELKE H.W., WANG G., GONZALES C.R., POWELL E.T., LE B., QUACH V.N. PAHs and metals in the soils of inner-city and suburban New Orleans, Louisiana, USA. Environ. Toxicol. Pharmacol. 18 (3), 243, 2004.

18. NIEUWOUDT C., PIETERS R., QUINN L.P., KYLIN H., BORGEN A.R., BOUWMAN H. Polycyclic aromatic hydrocarbons (PAHs) in soil and sediment from industrial, residential, and agricultural areas in central South Africa: An initial assessment. Soil Sediment Contam. 20 (2), 188, 2011.

19. AISLABIE J., BALKS M., ASTORI N., STEVENSON G., SYMONS R. Polycyclic aromatic hydrocarbons in fueloil contaminated soils, Antarctica. Chemosphere. 39 (13), 2201, 1999.

20. BRINDHA K., ELANGO L. PAHs contamination in groundwater from a part of metropolitan city, India: a study based on sampling over a 10 -year period. Environ. Earth Sci. 71 (12), 5113, 2014.

21. LI J., LI F., LIU Q. PAHs behavior in surface water and groundwater of the Yellow River estuary: evidence from isotopes and hydrochemistry. Chemosphere. 178, 143, 2017.

22. SUN Y., ZHANG S., LAN J., XIE Z., PU J., YUAN D., YANG H., XING B. Vertical migration from surface soils to groundwater and source appointment of polycyclic aromatic hydrocarbons in epikarst spring systems, southwest China. Chemosphere. 230, 616, 2019.

23. SAPCANIN A., CAKAL M., JACIMOVIC Z., PEHLIC E., JANCAN G. Soil pollution fingerprints of children playgrounds in Sarajevo city, Bosnia and Herzegovina. Environ. Sci. Pollut. Res. Int. 24 (12), 10949, 2017.

24. PRIBYLOVA P., KARES R., BORUVKOVA J., CUPR P., PROKES R., KOHOUTEK J., HOLOUBEK I., KLANOVA J. Levels of persistent organic pollutants and polycyclic aromatic hydrocarbons in ambient air of Central and Eastern Europe. Atmos. Pollut. Res. 3 (4), 494, 2012.

25. DJEDJIBEGOVIC J., MARJANOVIC A., SOBER M., SKRBO A., SINANOVIC K., LARSSEN T. R., GRUND M., FJELD E., ROGNERUD S. Levels of persistent organic pollutants in the Neretva River (Bosnia and Herzegovina) determined by deployment of semipermeable membrane devices (SPMD). J. Environ. Sci. Health B. 45 (2), 128, 2010.

26. LAMMEL G., KLÁNOVÁ J., ILIĆ P., KOHOUTEK J., GASIĆ B., KOVACIĆ I., LAKIĆ N., RADIĆ R. Polycyclic aromatic hydrocarbons in air on small spatial and temporal scales-I. Levels and variabilities. Atmos. Environ. 44, 5015, 2010.

27. LAMMEL G., KLÁNOVÁ J., ILIĆ P., KOHOUTEK J., GASIĆ B., KOVACIĆ I., ŠKRDLÍKOVÁ L. Polycyclic aromatic hydrocarbons in air on small spatial and temporal scales-II. Mass size distributions and gas-particle partitioning. Atmos. Environ. 44 (38), 5022, 2010.

28. CAO W., YIN L., ZHANG D., WANG Y., YUAN J., ZHU Y., DOU J. Contamination, Sources, and Health Risks Associated with Soil PAHs in Rebuilt Land from a Coking Plant, Beijing, China. Int. J. Environ. Res. Public Health. 16 (4), 670, 2019.

29. ILIĆ P., NIŠSIĆ T., ILIĆ S., STOJANOVIĆ BJELIĆ, LJ. The identification of new 'hotspot' of heavy metal contamination of soil in industrial zone. Pol. J. Environ. Stud. 29 (4), 2987, 2020. 
30. ILIĆ P., NIŠIĆ T., FAROOQI Z.U.R. Polycyclic Aromatic Hydrocarbons Contamination of Soil in an Industrial Zone and Evaluation of Pollution Sources. Pol. J. Environ. Stud. (accepted on 08/03/2020). 30 (1), 1, 2021.

31. KONONOVA M.M. Soil Organic Matter, $2^{\text {nd }}$ ed.; Publisher: Pergamon Press, Oxford. 378, 1966.

32. RULEBOOK on allowable quantities of dangerous and hazardous matters in soil and irrigation water and methods for their testing ("Official Gazette of the Republic of Srpska”, No. 56/16), 2016 [In Serbian].

33. REGULATION on the classification of waters and categorization of watercourses ("Official Gazette of the Republic of Srpska”, No. 42/01), 2001 [In Serbian].

34. US-EPA, Method 8270D. Semivolatile Organic Compounds by Gas Chromatography Mass Spectrometry. US Environmental Protection Agency, 2007.

35. KONSTANTINOVA E., MINKINA T., SUSHKOVA S., ANTONENKO E., KONSTANTINOV A. Levels, sources, and toxicity assessment of polycyclic aromatic hydrocarbons in urban topsoils of an intensively developing Western Siberian city. Environmental Geochemistry and Health. 1, 2019.

36. ZHANG J., YANG J.C., WANG R.Q., HOU H., DU X.M., FAN S.K., LIU J.S., DAI J.L. Effects of pollution sources and soil properties on distribution of polycyclic aromatic hydrocarbons and risk assessment. Sci. Total Environ. 463, $1,2013$.

37. JIAO H., WANG Q., ZHAO N., JIN B., ZHUANG X., BAI Z. Distributions and sources of polycyclic aromatic hydrocarbons (PAHs) in soils around a chemical plant in Shanxi, China. Int. J. Environ. Res. Public Health. 14 (10), 1198, 2017.

38. KIM A.W., VANE C.H., MOSS-HAYES V.L., BERIRO D.J., NATHANAIL C.P., FORDYCE F.M., EVERETT P.A. Polycyclic aromatic hydrocarbons (PAHs) and polychlorinated biphenyls (PCBs) in urban soils of Glasgow, UK. Earth Environ. Sci. Trans. R. Soc. Edinb. 108 (2-3), 231, 2018.

39. MORILLO E., ROMERO A.S., MAQUEDA C., MADRID L., AJMONE-MARSAN F., GRCMAN H., DAVIDSON C. M., HURSTHOUSE A.S., VILLAVERDE J. Soil pollution by PAHs in urban soils: a comparison of three European cities. Journal of Environmental Monitoring. 9 (9), 1001, 2007.

40. TSIBART A.S., GENNADIEV A.N. Polycyclic aromatic hydrocarbons in soils: sources, behavior, and indication significance (a review). Eurasian Soil Sci. 46 (7), 728, 2013.

41. TANG L., TANG X.Y., ZHU Y.G., ZHENG M.H., MIAO Q.L. Contamination of polycyclic aromatic hydrocarbons (PAHs) in urban soils in Beijing, China. Environ Int. 31 (6), 822, 2005.

42. NAM J.J., THOMAS G.O., JAWARD F.M., STEINNES E., GUSTAFSSON O., JONES K.C. PAHs in background soils from Western Europe: influence of atmospheric deposition and soil organic matter. Chemosphere. 70 (9), 1596, 2008

43. RADU V.M., IONESCU P., DEAK G., DIACU E., IVANOV A.A., ZAMFIR S., MARCUS M.I. Overall assessment of surface water quality in the Lower Danube River. Environ. Monit. Assess. 192 (2), 135, 2020.

44. PARRA Y.J., OLOYEDE O.O., PEREIRA G.M., DE ALMEIDA LIMA P.H.A., DA SILVA CAUMO S.E., MORENIKEJI O.A., DE CASTRO VASCONCELLOS P. Polycyclic aromatic hydrocarbons in soils and sediments in Southwest Nigeria. Environ. Pollut. 259, 113732, 2020.

45. LIU C.W., LIN K.H., KUO Y.M. Application of factor analysis in the assessment of groundwater quality in a Blackfoot disease area in Taiwan. Science of the Total Environment. 313 (1-3), 77, 2003.

46. HARRISON R.M., SMITH D.J.T., LUHANA L. Source apportionment of atmospheric polycyclic aromatic hydrocarbons collected from an urban location in Birmingham, UK. Environ. Sci. Technol. 30 (3), 825, 1996.

47. DAVIS E., WALKER T.R., ADAMS M., WILLIS R., NORRIS G.A., HENRY R.C. Source apportionment of polycyclic aromatic hydrocarbons (PAHs) in small craft harbor $(\mathrm{SCH})$ surficial sediments in Nova Scotia, Canada. Sci. Total Environ. 691, 528, 2019.

48. IWEGBUE C.M., OBI G., AGANBI E., OGALA J.E., OMO-IRABOR O.O., MARTINCIGH B.S. Concentrations and health risk assessment of polycyclic aromatic hydrocarbons in soils of an urban environment in the Niger Delta, Nigeria. J. Toxicol. Environ. Health Sci. 8 (3), 221, 2016.

49. TEPANOSYAN G., SAHAKYAN L., BELYAEVA O., MAGHAKYAN N., SAGHATELYAN A. Human health risk assessment and riskiest heavy metal origin identification in urban soils of Yerevan, Armenia. Chemosphere. 184, 1230, 2017.

50. BAO H., HOU S., NIU H., TIAN K., LIU X., WU F. Status, sources, and risk assessment of polycyclic aromatic hydrocarbons in urban soils of Xi'an, China. Environmental Science and Pollution Research. 25 (19), 18947, 2018

51. UNCUMUSAOĞLU A.A., MUTLU E. Evaluating spatial andtemporal variation in Tuzaklıpond water using multivariatestatistical analysis. Pol. J. Environ. Stud. 28 (5), 1, 2019.

52. DOŁEGOWSKA S., MICHALIK A. The use of a geostatistical model supported by multivariate analysis to assess the spatial distribution of mercury in soils from historical mining areas: Karczówka Mt., Miedzianka Mt., and Rudki (south-central Poland). Environ. Monit. Assess. 191 (5), 302, 2019. 
